\title{
The anticancer effects of Saccharina japonica on 267B1/K-ras human prostate cancer cells
}

\author{
MI JEONG JO ${ }^{1}$, HYUNG RAK KIM ${ }^{2}$ and GUN DO KIM ${ }^{1}$ \\ Departments of ${ }^{1}$ Microbiology, College of Natural Sciences, and ${ }^{2}$ Food Science and Nutrition, \\ College of Fisheries Sciences, Pukyung National University, Busan 608-737, Republic of Korea
}

Received June 7, 2012; Accepted July 30, 2012

DOI: $10.3892 /$ ijo.2012.1612

\begin{abstract}
Saccharina japonica (S. japonica), a brown macroalga, has been used as a traditional medicine in Korea for thousands of years. In this study, the potential anticancer effects of $S$. japonica were evaluated on 267B1/K-ras human prostate cancer cells. The exposure of cells to the extract induced inhibition of cell growth by increasing the number of apoptotic cells with cell shrinkage and inhibition of cell cycle progression. The effects of the extract on the cells were assessed by studying the cleavage of caspases and the target proteins of caspases. The increased expression of various cleaved caspases and changed expression of other proteins related in the apoptosis pathway were observed. 4'-6-Diamidino-2-phenylindole (DAPI) and immunofluorescence staining showed the cells undergoing apoptosis. Apoptosis induced changes in the expression of proteins involved in a variety of signaling pathways such as endocellular reticulum (ER) stress, death receptor and mammalian target of rapamycin (mTOR)-FoxO-mediated pathways. The data suggest that the extract (n-hexane sub-fraction) of $S$. japonica, induces apoptosis and cell cycle arrest in 267B1/K-ras human prostate cancer cells, and has potential as a complementary agent for cancer prevention.
\end{abstract}

\section{Introduction}

Prostate cancer is the most common non-skin cancer in men, and the second leading cause of death in male cancer patients after lung cancer (1). Epidemiological studies show that in Asia the incidence of prostate cancer is lower compared to that in the West (2). There is increasing evidence showing that habitual consumption of tea, soybean and its products, which are rich in catechins and flavonoids, by Asian men is correlated with a reduction in a number of cancers or their prevention, including cancer of the prostate gland. Treatments for prostate

Correspondence to: Professor Gun-Do Kim, Department of Microbiology, College of Natural Sciences, Pukyong National University, 45 Yongso-Ro, Nam-Gu, Busan 608-737, Republic of Korea E-mail: gundokim@pknu.ac.kr

Key words: Saccharina japonica, n-hexane fraction, 267B1/K-ras, apoptosis, cell cycle arrest cancer also include surgery, orchiectomy, hormonal therapy, radiation and chemotherapy (3).

Recent studies have been carried out to find chemopreventive and/or chemo-therapeutic agents targeting on cancer from edible and natural resources such as fruits, vegetables, and terrestrial plants (4). As one of the well-known natural resources, seaweeds are well-balanced natural sources with a high degree of trace elements, and strongly advised for fast growing children and pregnant women (5). Edible seaweeds have high nutritional values as sources of vitamins, minerals, and non-caloric dietary fibers and as potential sources of biological active ingredients (6). Marine organisms have emerged as one of the important sources for dietary supplements and a number of them are potentially active and useful source of medicine. Their metabolites such as flavonoid and other phenolic compounds are widely used in life science research and provide chances for discovery-phase of new drug development $(7,8)$.

The brown alga Saccharina japonica ( $S$. japonica) is frequently consumed in Korea, Japan and China, and has been used for more than a thousand years as a nutraceutical in traditional Chinese medicine. Dietary application of Saccharina sp. has been reported to reduce the risk of intestinal or mammary cancer in animal studies (9). Furthermore, research has been focused on the isolation and function of Saccharina sp., which revealed multiple biological activities such as immunopotentiating substances, anti-inflammatory, anti-tumor, anti-oxidant, anti-coagulant, and anti-viral activities (10).

Apoptosis (programmed cell death) is characterized by specific morphological and biochemical changes, including cell shrinkage, chromatin condensation, and inter-nucleosomal cleavage of genomic DNA. Apoptotic cells ultimately break up into plasma membrane-bound vesicles called apoptotic bodies that are rapidly phagocytosed by macrophages and neighboring epithelial cells. At the molecular level, apoptosis is tightly regulated and mainly harmonized by the activation of the caspases $(11,12)$.

Caspases are aspartate-specific cysteine proteases and are expressed as pro-enzymes. Caspase activation involves the proteolytic processing and a substantial body of evidence supports a cascade model. Initiator caspases such as caspase-2, $-8,-9$ and -10 instigate the apoptotic cascade and lead to the activation of effector caspases, which include caspase-3, -6 and -7. Caspases cause cell death by cleaving a number of cellular proteins including nuclear lamins, DNA repair enzymes such as 
poly(ADP-ribose) polymerase (PARP), and cytoskeletal proteins such as actin, fodrin and gelsolin (13-17). Fragmentation of DNA during apoptosis is caused by an enzyme known as DNA fragmentation factor (DFF) (18).

Cell proliferation is governed primarily by regulation of the cell cycle, which consists of four distinct sequential phases (G0/G1, S, G2, and M). Transition through the G1-phase of the cell cycle and entry into the S-phase requires binding and activation of cyclin/cyclin-dependent kinase (CDK) complexes, predominantly cyclin D/CDK4 or CDK6 and cyclin E/CDK2 (19). Cyclin-dependent kinase inhibitors (CKIs) are naturally occurring gene products that inhibit cyclin/CDK activity, leading to G1-phase arrest. $\mathrm{p} 21^{\text {waf1 }}$ (p21) is a primary negative regulator and negatively regulates the kinase activity of cyclin/ CDK complexes. These inhibitors block cell cycle progression by binding and inactivating the cyclin/CDK complex in the G1-phase, leading to cell cycle arrest (20).

In this study, we examined anticancer effects which are mediated by multiple pathways of endocellular reticulum (ER) stress, death receptor and mammalian target of rapamycin (mTOR)-Fox leading apoptosis and cell cycle arrest in 267B1/K-ras, 267B1 human prostate cancer cells transformed by K-ras, by treatment with the extract (n-hexane sub-fraction) of $S$. japonica, marine macro-algae.

\section{Materials and methods}

\section{Sample preparation}

Preparation of seaweeds. S. japonica was harvested from Kijang aquaculture farm, Korea. The samples were dried in cold-air drier $\left(60^{\circ} \mathrm{C}\right)$ for $40 \mathrm{~h}$, ground with a hammer mill, and then the dried powder was stored at $-20^{\circ} \mathrm{C}$ until used.

Extraction and fractionation. The dried powder $(2 \mathrm{~kg})$ of $S$. japonica was refluxed with ethyl alcohol $(95 \%, \mathrm{v} / \mathrm{v}, 51$ $\mathrm{x} 3$ times) for $3 \mathrm{~h}$. The extract (446.0 g) was suspended in $\mathrm{H}_{2} \mathrm{O}$ :ethyl alcohol $(9: 1, \mathrm{v} / \mathrm{v})$ and partitioned with $\mathrm{n}$-hexane, dichloromethane, ethyl acetate (EtOAc), n-butanol (n-BuOH), and water in sequence, yielding the $\mathrm{n}$-hexane $(135.5 \mathrm{~g})$, dichloromethane (18.1 g), EtOAc (39.6 g), n-BuOH (55 g), and water $(162.8 \mathrm{~g})$ fractions. The $\mathrm{n}$-hexane fraction was subjected to preparative size exclusion column of Shim-pack PREP-ODS (500 mm x $21.2 \mathrm{~mm}$, Shimadzu Co., Tokyo,Japan). An exclusion HPLC apparatus consisted of a pump (Shimadzu LC-6AD), a photodiode array detector (Shimadzu SPDM20A), an online degasser (Shimadzu DUG-20A3), an autosampler (SIL-20A), a fraction collector (Shimadzu FRC-10A), a system controller (CBM-20A), and a Shimadzu LC solution (ver. 1.22sp). The $\mathrm{n}$-hexane fraction was chromatographed on a Shim-pack PREP-ODS column eluting with methanol at a flow rate of 5.0 $\mathrm{ml} / \mathrm{min}$ and monitored at $240 \mathrm{~nm}$. The fraction was separated into four fractions (GS1-GS4). The GS3 fraction was chromatographed over Phenomenex C18-ODS $(5 \mu \mathrm{m}, 100 \AA$ A 300 $\mathrm{mm} \times 5 \mathrm{~mm}$, Phenomenex Co., Tokyo, Japan). A preparative ODS HPLC system was similar to the exclusion HPLC system except for a binary pump (Phenomenex LC-6AD) and a column oven $\left(35^{\circ} \mathrm{C}\right.$, Phenomenex CTO-20A). The separation of GS3 fraction was conducted using mobile phase water (solvent A) and methanol (solvent B). The elution profile consisted of a linear gradient from 20 to $70 \% \mathrm{~B}$ solvent for $90 \mathrm{~min}$. The flow rate was $7.0 \mathrm{ml} / \mathrm{min}$, and detection was performed at $216 \mathrm{~nm}$.
Fifteen sub-fractions (GS3-ODS1-GS3-ODS15) were tested for cell viability against prostate cancer cells and GS3-ODS4 sub-fraction is selected for the studies.

Cell culture and treatment of the extract. Human epithelial cell line (267B1) established from fetal prostate tissue can be malignantly transformed by a biological carcinoma, and can serve as a useful model for research of the progression steps of carcinogenesis. Activated K-ras was introduced into 267B1 cells by infection with the Kirsten murine sarcoma virus $(1,21)$. The established 267B1/K-ras cells are immortalized and contained the essential characteristics of primary human prostate epithelial cells such as morphology, expression of cytokeratins. The transformed 267B1/K-ras human prostate cancer cells and HEK293 human embryonic kidney cells were used for the experiments. The 267B1/K-ras cells were cultured in RPMI-1640 with L-glutamine (Lonza Group Ltd., Basel, Switzerland) containing 10\% heat-inactivated fetal bovine serum (Lonza Group Ltd.) and $1 \% 100 \mathrm{U} / \mathrm{ml}$ penicillin and $100 \mu \mathrm{g} / \mathrm{ml}$ streptomycin (PAA Laboratories $\mathrm{GmbH}, \mathrm{PA}$, Austria). HEK293 cells were cultured in Dulbecco's modified Eagle's medium with high glucose (DMEM/high glucose, Thermo Scientific Hyclone, Logan, UT, USA), 10\% heatinactivated fetal bovine serum (Thermo Scientific Hyclone) and $1 \% 100 \mathrm{U} / \mathrm{ml}$ penicillin and $100 \mu \mathrm{g} / \mathrm{ml}$ streptomycin (PAA Laboratories $\mathrm{GmbH}$ ) at $37^{\circ} \mathrm{C}$ in a humidified atmosphere of $5 \% \mathrm{CO}_{2}$. The fraction, dissolved in dimethylsulfoxide (DMSO) (ATCC, Manassas, VA, USA), was added to the culture media to the final concentration specified in the text. The final concentration of DMSO in the culture medium was not exceeded $0.04 \%(\mathrm{v} / \mathrm{v})$, and the same concentration of DMSO was added to the control dishes.

Cell viability assay. For the cell viability assay, 267B1/K-ras cells and HEK293 cells in exponential growth phase were suspended at a final concentration of $1 \times 10^{5}$ cells $/ \mathrm{ml}$ in each medium containing $10 \%$ FBS in 96-well cell culture plate (SPL Lifesciences, Gyeonggi, Korea) in triplicate. The cells were then treated with various concentrations $(10,20,30,40$ and $50 \mu \mathrm{g} / \mathrm{ml})$ of extracted fraction and incubated for $24 \mathrm{~h}$. After the treatment, $10 \mu 1$ of EZ-Cytox Cell Viability Assay Solution WST- ${ }^{\circledR}$ (Daeil Lab Service, Jong-No, Korea) was added onto each well and the cells were further incubated at $37^{\circ} \mathrm{C}$ for $3 \mathrm{~h}$ and then read at $460 \mathrm{~nm}$ with ELISA reader (Molecular Devices, Sunnyvale, CA, USA).

Western blot analysis. The cultured 267B1/K-ras cells in $150 \mathrm{~mm}$ dish (Corning Incorporated Life Science, Lowell, MA, USA) were treated with the extract for $24 \mathrm{~h}$ and then washed with ice-cold PBS (phosphate-buffered saline) and harvested by scrapping. The harvested cells were collected by centrifugation, lysed in ice-cold lysis buffer [50 mM Tris-Cl (pH 7.5), $150 \mathrm{mM}$ $\mathrm{NaCl}, 1 \mathrm{mM}$ DTT, $0.5 \%$ NP-40, $1 \%$ Triton X-100, 1\% deoxycholate, $0.1 \%$ SDS and proteinase inhibitors (PMSF, EDTA, aprotinin, leupeptin, prostatin A)] (Intron Biotechnology, Gyeonggi, Korea). After incubation on ice for $30 \mathrm{~min}$, the insoluble materials were removed by centrifugation at $14,000 \mathrm{rpm}$ for $20 \mathrm{~min}$ at $4^{\circ} \mathrm{C}$. The protein contents of the cell lysates were determined by a Protein Quantification kit (CBB solution $\left.{ }^{\circledR}\right)$ (Dojindo Molecular Technologies, Rockville, MD, USA) with 
bovine serum albumin (BSA) as standard. An aliquot from each sample was boiled for $4 \mathrm{~min}$, and then resolved by $12 \%$ SDS-polyacrylamide gel electrophoresis (SDS-PAGE). The proteins were electro-transferred to a nitrocellulose membrane (PALL Life Sciences, MI, USA) and then blocked in PBST buffer (135 mM NaCl, $2.7 \mathrm{mM} \mathrm{KCl,} 4.3 \mathrm{mM} \mathrm{NaPO}, 1.4 \mathrm{mM}$ $\mathrm{KH}_{2} \mathrm{PO}_{4}, 0.5 \%$ Tween-20) containing 5\% skim milk for overnight at $4^{\circ} \mathrm{C}$. The blots were probed with the primary antibody (Cell Signaling Technology Inc., Beverly, MA, USA) and then washed three times in PBST, followed by incubation for $1 \mathrm{~h}$ with horseradish peroxidase-coupled anti-rabbit IgG or anti-mouse IgG as second antibodies (Cell Signaling Technology Inc.). The blots were then washed in PBST and visualized by an enhanced chemiluminescent (ECL) detection solution (Pierce, Rockford, IL, USA).

Treatment of $z V A D-F M K$. To investigate the involvement of caspases in apoptosis, 267B1/K-ras cells were seeded at a final concentration of $1 \times 10^{5}$ cells/ml in RPMI-1640 media containing $10 \%$ FBS and $1 \%$ penicillin-streptomycin in 96-well cell culture plate in triplicate. The cells were then pre-incubated with $20 \mu \mathrm{M}$ of a caspase inhibitor, zVAD-FMK (dissolved in DMSO) for $1 \mathrm{~h}$ prior to treating with the concentration of $30 \mu \mathrm{g} / \mathrm{ml}$ of the extract. zVAD-FMK (carbobenzoxy-valyl-alanyl-aspartyl-[O-methyl]fluoromethylketone, Tocris Bioscience, Ellisville, MO, USA) is a cell-permeant pan-caspase inhibitor that irreversibly binds to the catalytic site of caspase proteases and can inhibit induction of apoptosis. After treatment of extract for $24 \mathrm{~h}, 10 \mu \mathrm{l}$ of EZ-Cytox Cell Viability Assay Solution WST-1 (Daeil Lab Service) was added onto each well and the cells were further incubated at $37^{\circ} \mathrm{C}$ for $3 \mathrm{~h}$ and then read at $460 \mathrm{~nm}$ with ELISA reader (Molecular Devices).

DAPI staining. $267 \mathrm{~B} 1 / \mathrm{K}$-ras cells were cultured at $37^{\circ} \mathrm{C}$ with $5 \%$ $\mathrm{CO}_{2}$ on coverglass-bottom dishes (SPL Life Sciences) in RPMI1640 media containing $10 \%$ FBS and $1 \%$ penicillin-streptomycin and then incubated for $24 \mathrm{~h}$ with the concentration of 20 and $30 \mu \mathrm{g} / \mathrm{ml}$ of the extract. To see the formation of apoptosome, cells were rinsed twice with $1 \mu \mathrm{g} / \mathrm{ml}$ of DAPI (4',6-diamidine2'-phenylindole dihydrochloride, Roche Applied Science, Indianapolis, IN, USA) in methanol (Sigma-Aldrich, St. Louis, MO, USA) and stained by the addition of DAPI solution. After incubation in dark at $37^{\circ} \mathrm{C}$ for $20 \mathrm{~min}$, cells were rinsed once with methanol (Sigma-Aldrich). Stained cells on the slides were mounted in Prolong Gold Antifade Reagent (Invitrogen, Eugene, OR, USA) followed by observation under a Nikon ECLIPS 50i microscope equipped with charged-coupled device (CDD) camera. Images were captured and processed with High-Content Analysis Software (Cambridge Healthtech Ins., Needham, MA, USA).

DNA fragmentation. For detecting genomic DNA fragmentation, the treated 267B1/K-ras cells were washed with ice-cold PBS buffer and harvested. The collected cells were handled by following protocol of DNeasy ${ }^{\circledR}$ blood \& tissue kit (Qiagen $\mathrm{GmbH}$, Hilden, Germany). The isolated DNA was analyzed on a $1.5 \%$ agarose gel (Life Technologies Inc., Grand Island, NY, USA) with UV transilluminator (Vilber Lourmat, Marne-la-Vallee, France) after ethidium bromide (Sigma-Aldrich) staining. Isolated DNA was mixed with 6x loading dye (Promega, Madison, WI, USA) and loaded on the agarose gel with $1 \mathrm{~kb}$ DNA Ladder (Promega) for identify the size of DNA.

Immunofluorescence stain. 267B1/K-ras cells were cultured at $37^{\circ} \mathrm{C}$ with $5 \% \mathrm{CO}_{2}$ on coverglass-bottom dishes in RPMI-1640 media containing $10 \% \mathrm{FBS}$ and $1 \%$ penicillin-streptomycin, were incubated for $24 \mathrm{~h}$ with the concentration of 20 and $30 \mu \mathrm{g} /$ $\mathrm{ml}$ of the extract. Cells were fixed with $4 \%$ formaldehyde (Junsei Chemical Co., Ltd., Japan) for $15 \mathrm{~min}$ at room temperature and blocked for $1 \mathrm{~h}$ in 5\% mouse and rabbit normal serum (Santa Cruz Biotechnology, Inc., CA, USA) of host of primary antibodies and $0.3 \%$ Triton X-100. Fixed and blocked cells were incubated with $0.1 \mu \mathrm{g} / \mathrm{ml}$ of primary antibodies (cleaved caspase-3 and $\beta$-actin) (Cell Signaling Technology Inc.) for $3 \mathrm{~h}$ and then treated with $0.1 \mu \mathrm{g} / \mathrm{ml}$ of anti-mouse $\mathrm{IgG}(\mathrm{H}+\mathrm{L}), \mathrm{F}\left(\mathrm{ab}^{\prime}\right) 2$ Fragment (Alexa Fluor ${ }^{\circledR} 555$ Conjugate) and/or anti-rabbit IgG $(\mathrm{H}+\mathrm{L}), \mathrm{F}\left(\mathrm{ab}^{\prime}\right) 2$ Fragment (Alexa Fluor ${ }^{\circledR} 488$ Conjugate) (Cell Signaling Technology Inc.) for $1 \mathrm{~h}$. Stained cells on the slides were mounted in Prolong Gold Antifade Reagent followed by observation under a Nikon ECLIPS 50i microscope equipped with CDD camera. Images were captured and processed with High-Content Analysis software.

Fluo-3/AM assay. 267B1/K-ras cells cultured at $37^{\circ} \mathrm{C}$ with $5 \%$ $\mathrm{CO}_{2}$ on cover glass-bottom dish in RPMI-1640 media containing $10 \%$ FBS and $1 \%$ penicillin-streptomycin, were incubated for $24 \mathrm{~h}$ with the concentration of 20 and $30 \mu \mathrm{g} / \mathrm{ml}$ of the extract. In order to detect the change of intracellular $\mathrm{Ca}^{2+}$ concentration, the treated cells were incubated for $30 \mathrm{~min}$ at room temperature with $1.5 \mu \mathrm{M}$ of Fluo-3/AM (Invitrogen). The cells on the slides were mounted in Prolong Gold Antifade Reagent followed by observation under a Nikon ECLIPS 50i microscope equipped with CDD camera and images were captured and processed with High-Content Analysis software.

FACS analysis. To investigate the mechanisms of growth inhibition, 267B1/K-ras cells in 100-mm cell culture dish (SPL Life Sciences) were incubated with various dose of the extract for $24 \mathrm{~h}$. Distribution of cell cycle was examined using flow cytometry. Briefly, cells were harvested by trypsinization, fixed in $99 \%$ ethanol at $4^{\circ} \mathrm{C}$ for overnight. And then resuspended in PBS containing RNase A $(10 \mu \mathrm{g} / \mathrm{ml})$ and incubated for $1 \mathrm{~h}$ at $37^{\circ} \mathrm{C}$. DNA was stained with propidium iodide $(40 \mu \mathrm{g} / \mathrm{ml})$ (Sigma-Aldrich) for $10 \mathrm{~min}$ and cells were then examined by FACSCalibur (Becton-Dickinson, Mountain View, CA, USA).

Statistical analysis. The GraphPad Prism 5.0 for window was used to determine the statistical significance of differences between values for various experimental and control group. Determinations were performed in triplicate and the results are presented as mean \pm SEM. In cases where no error bar is seen in the graph, the variation is small and thus, the bar is hidden behind the bar. ANOVA post hoc and subsequently Dunnett's multiple comparison tests were used for statistical analysis.

\section{Results and Discussion}

Effects of the extract on cell proliferation. In order to understand the effects of the extract on cell proliferation, 267B1/K-ras 


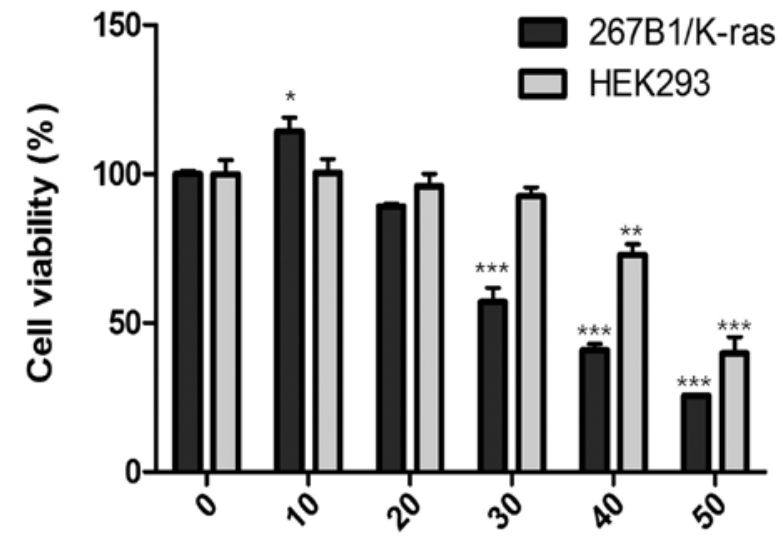

Concentration of S. japonica $(\mu \mathrm{g} / \mathrm{ml})$

Figure 1. Growth inhibition of the extract on HEK293 and 267B1/K-ras cells The cells were treated with $10-50 \mu \mathrm{g} / \mathrm{ml}$ of the extract for $24 \mathrm{~h}$. Bars represent the mean \pm SEM of three experiments. ${ }^{*} \mathrm{P}<0.05 ;{ }^{* *} \mathrm{P}<0.01 ;{ }^{* * *} \mathrm{P}<0.001$.

cells were treated with the extract (n-hexane sub-fraction) of $S$. japonica followed by cell viability assay. The assay showed decreased cell viability at concentration of $35 \mu \mathrm{g} / \mathrm{ml}\left(\mathrm{IC}_{50}\right)$ (Fig. 1). Treatment with 10 and $20 \mu \mathrm{g} / \mathrm{ml}$ of the extract had lower effect on the viability of the 267B1/K-ras cells which suggested that extensive death of the cells was only occurring at the higher concentration. However, the effect of 20 and $30 \mu \mathrm{g} / \mathrm{ml}$ of the extract on HEK293 human embryonic kidney cells are relatively non-toxic. To examine the effects of the extract on the changes of cell population and morphology, the cells were treated with the extract at the concentration of 20 and $30 \mu \mathrm{g} / \mathrm{ml}$ for $24 \mathrm{~h}$ and then observed under the inverted microscope (Fig. 2A). Compared with control, most of the cells were shrunken and some of cells floated on the medium. Cell population was also dramatically reduced in the medium containing the extract with the concentration of $30 \mu \mathrm{g} / \mathrm{ml}$. Further experiments were carried out to determine whether this anti-proliferative effect of the extract on the viability of $267 \mathrm{~B} 1 / \mathrm{K}$-ras cells was closely associated with apoptotic cell death. Morphological analysis following DAPI stain was performed to analyze the cells with nuclear chromatin condensation and apoptotic bodies (Fig. 2B). The results of DAPI stain showed overall different forms in the treated cells compared to untreated control cells. The cells treated with 20 and $30 \mu \mathrm{g} / \mathrm{ml}$ of the extract had reduced cell density, increased chromatin condensation and incomplete nuclear membrane, so the extract may be considered as an inducer of apoptosis on 267B1/K-ras cells.

The extract of S. japonica induces apoptosis. There are two apoptotic pathways; the extrinsic death receptor-mediated pathway and the intrinsic mitochondria-mediated pathway. The truncated Bid protein provides cross-talk between the two. Both of these pathways are regulated by caspases, which are responsible, either directly or indirectly, for the cleavages of cellular proteins, a characteristic of apoptosis.

Stressed endocellular reticulum (ER) induces increased level of cellular calcium ion that activates specific proteins in cells. Activation of calcium-dependent proteases such as calpain is thought to play an important role in apoptotic cell death. In addition, several studies have shown that calpain can contribute to tumor death, and calpain inhibitors have been used to block apoptosis. Since calpain is activated by elevated intracellular $\mathrm{Ca}^{2+}$ concentration, 267B1/K-ras cells were tested for the change of intracellular $\mathrm{Ca}^{2+}$ concentration (Fig. 4). The green fluorescent light, indicating the concentration of cellular calcium ion, was increased based on the treatment time with $30 \mu \mathrm{g} / \mathrm{ml}$ of the extract (Fig. 4). The activity of calpain in 267B1/K-ras cells

A Control $20 \mu \mathrm{g} / \mathrm{ml}$ $30 \mu \mathrm{g} / \mathrm{ml}$


B

Control

$20 \mu \mathrm{g} / \mathrm{m} \ell$

$30 \mu \mathrm{g} / \mathrm{ml}$



Figure 2. The effect of 20 and $30 \mu \mathrm{g} / \mathrm{ml}$ of the extract on 267B1/K-ras cells. (A) Cell population was visualized by an inverted microscope (magnification $\mathrm{x} 100$ ). (B) By DAPI staining, the cells clearly show condensed chromatin or fragmented nuclei which were taken as apoptotic bodies (magnification x1,000). 
A



$(\mu \mathrm{g} / \mathrm{m} \ell)$

Phospho-Chk2 (Thr68)

cdc25A

p21 $1_{\text {waf1/cip } 1}$

Phopho-cdc2 (Tyr15)

B

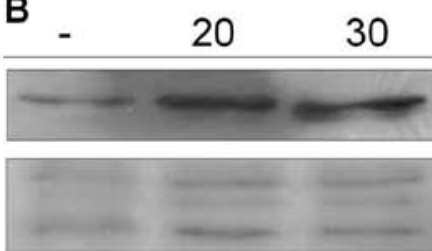

$(\mu \mathrm{g} / \mathrm{m} \ell)$

Calpain 1

Caspase-12

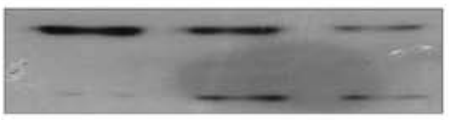

Caspase-9

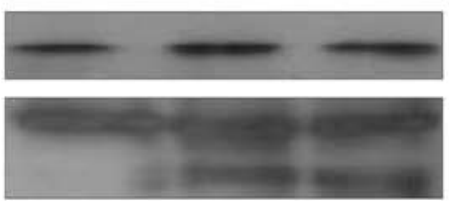

Cleaved caspase- 6

Caspase-7

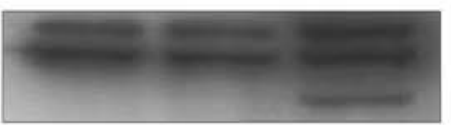

Lamin A/C

Cleaved Lamin AVC
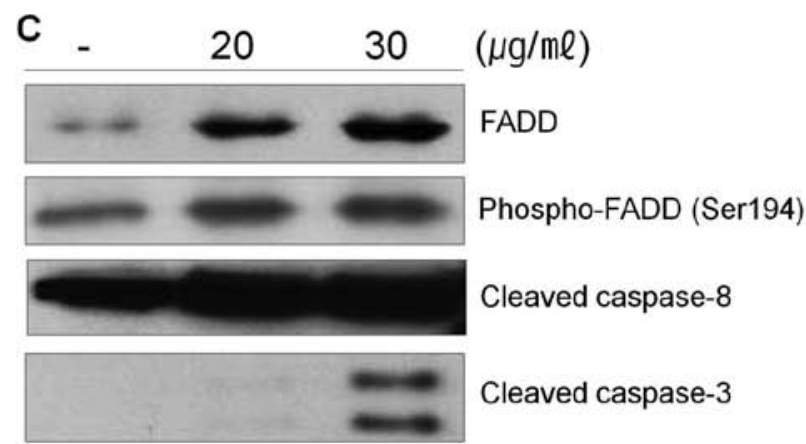

Cleaved caspase-3

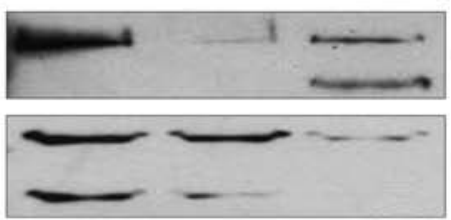

Cleaved PARP

DFF45/DFF35
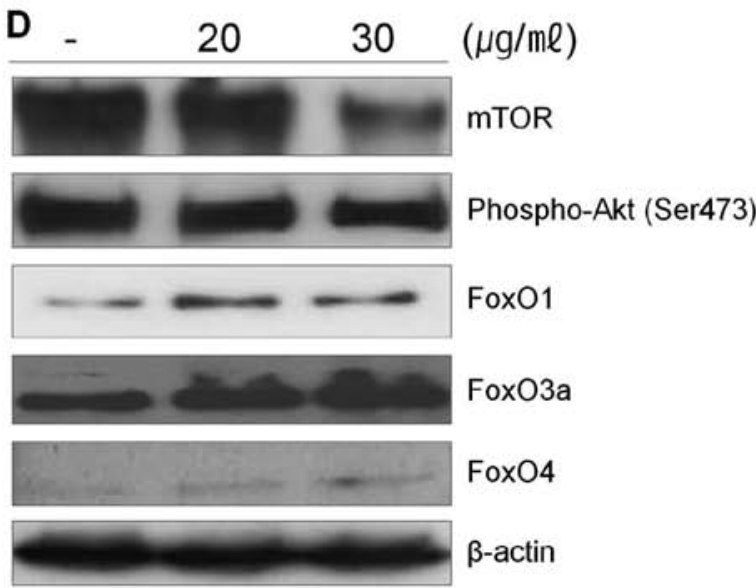

Figure 3. Western blot analysis of the proteins involved in cell cycle arrest (A) and apoptosis (B-D) on 267B1/K-ras cells. The cells were treated with 20 and $30 \mu \mathrm{g} / \mathrm{ml}$ of the extract for $24 \mathrm{~h}$, respectively. Cellular proteins were separated by SDS-PAGE and detected with indicated primary antibodies. $\beta$-actin was used as the internal control.

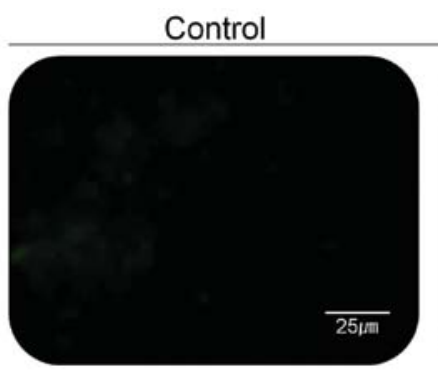

$3 \mathrm{~h}$


Figure 4. Increased intracellular $\mathrm{Ca}^{2+}$ concentration by the extract. In order to detect the changes of intracellular $\mathrm{Ca}^{2+}$ concentration, the treated cells $(30 \mu \mathrm{g} / \mathrm{ml}$ of the extract) were incubated for $30 \mathrm{~min}$ at room temperature with $1.5 \mu \mathrm{M}$ of Fluo-3/AM, indicator of intracellular $\mathrm{Ca}^{2+}$. The intensity of fluorescence was increased as time-dependent manner and the highest intensity was detected at $6 \mathrm{~h}$ of the extract treatment time (magnification $\mathrm{x} 400$ ). treated with the extract was assessed in cell lysates using western blot analysis (Fig. 3B). The results shown that 267B1/K-ras cells treated with the extract contained the lysed form of calpain. Lysis of the calpain is associated with calpain activation during apoptosis (22). To examine whether calpain is involved in the extract-induced apoptosis, ER-specific effectors are examined (Fig. 3B). Caspase-12 locates on the cytoplasmic side of ER and is proteolytically activated following ER stress and calpain activation. Activation of caspase- 12 was observed after treatment of the extract (Fig. 3B). After its activation at the ER, caspase-12 cleaves procaspase-9, leading to activation of caspase-3. ER stress induced processing of procaspase- 9 can occur in the absence of cytochrome $c$ release, which argues that caspase-12 triggers directly caspase- 9 activation and apoptosis, independently of the mitochondrial cytochrome c/Apaf-1 pathway (23).

The death receptor mediated apoptotic pathway has been proposed as a therapeutic target of cancer. Since the Fas/FasL system is also a key signal transduction pathway of apoptosis, we examined the involvement of the Fas/FasL system in 267B1/K-ras cells after treated with the extract. The cell surface receptor Fas has a fas-associated protein with death domain (FADD) in the cytolasmic domain. Once the death signal factors bind to Fas, the FADD is phosphorylated. To 
A

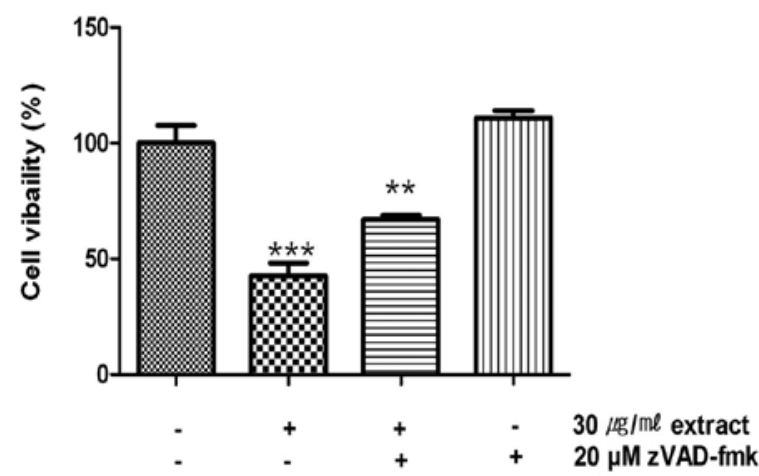

B

$10 \mathrm{kbp}$

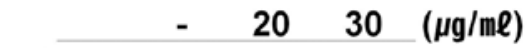

$3 \mathrm{kbp}$

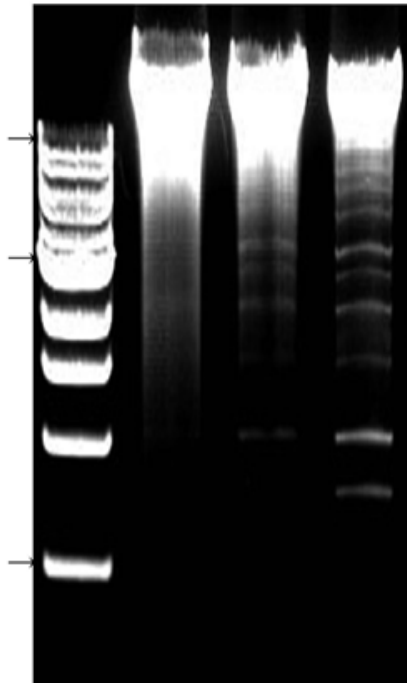

Figure 5. Caspase-dependent apoptosis and DNA fragmentation in the treated cells. For caspase activity assay (A), the cells were treated with $30 \mu \mathrm{g} / \mathrm{ml}$ of the extract for $24 \mathrm{~h}$ after pre-incubation with zVAD-FMK, a caspase inhibitor, for $1 \mathrm{~h}$. Bars represent the mean $\pm \mathrm{SEM}$ of three experiments. ${ }^{*} \mathrm{P}<0.05$; ${ }^{* *} \mathrm{P}<0.01$. For genomic DNA fragmentation (B), the isolated DNA from the treated cells was analyzed on a $1.5 \%$ agarose gel with $1 \mathrm{~kb}$ DNA ladder.

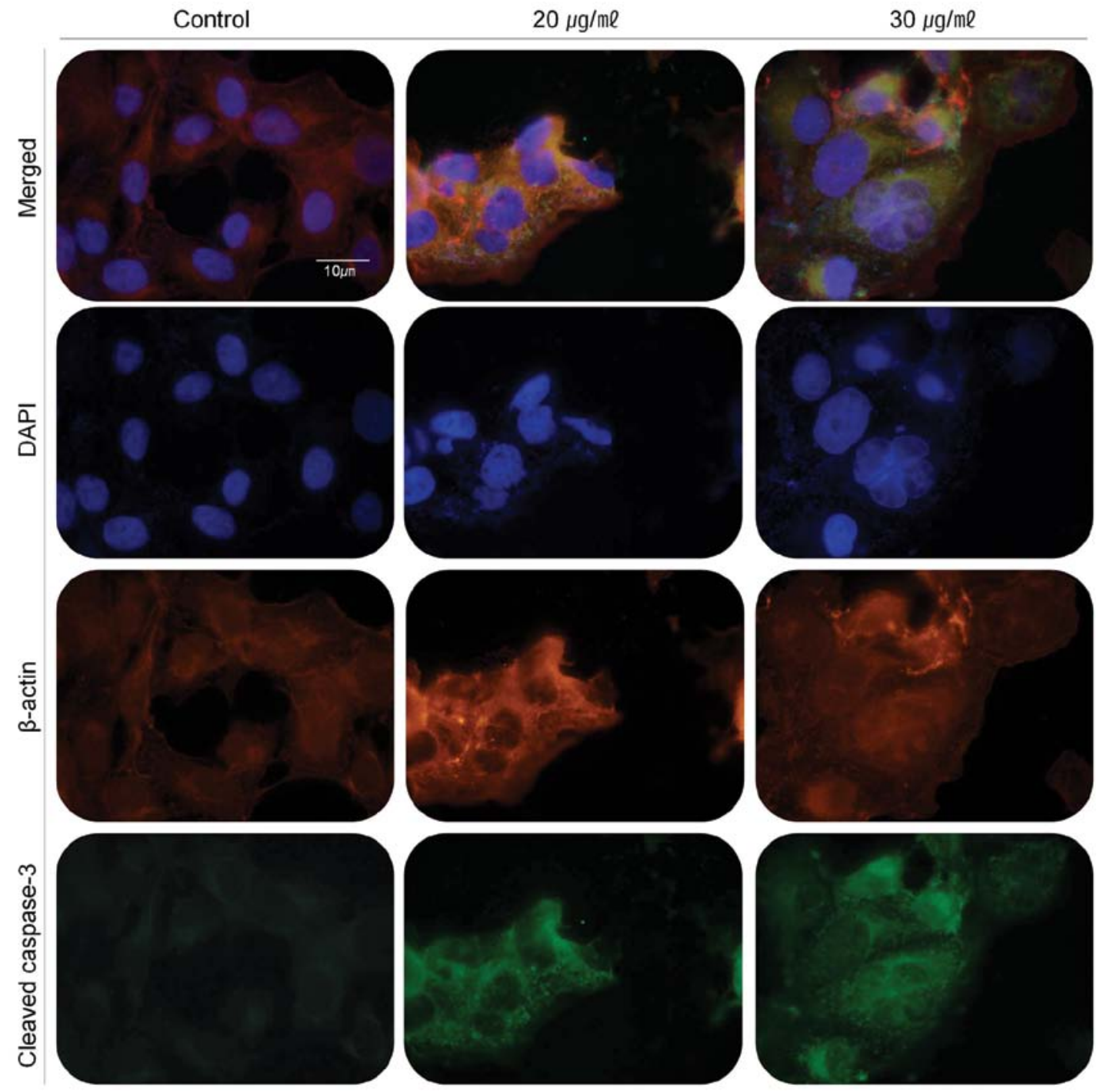

Figure 6. Immunofluorescence microscopy images of cleaved caspase-3 (green), $\beta$-actin (red) and nuclei (blue). The cells, stained with immunofluorescent specific antibodies, on the slides were mounted in an antifade reagent followed by observation under a Nikon ECLIPS 50i microscope (magnification x1,000). 

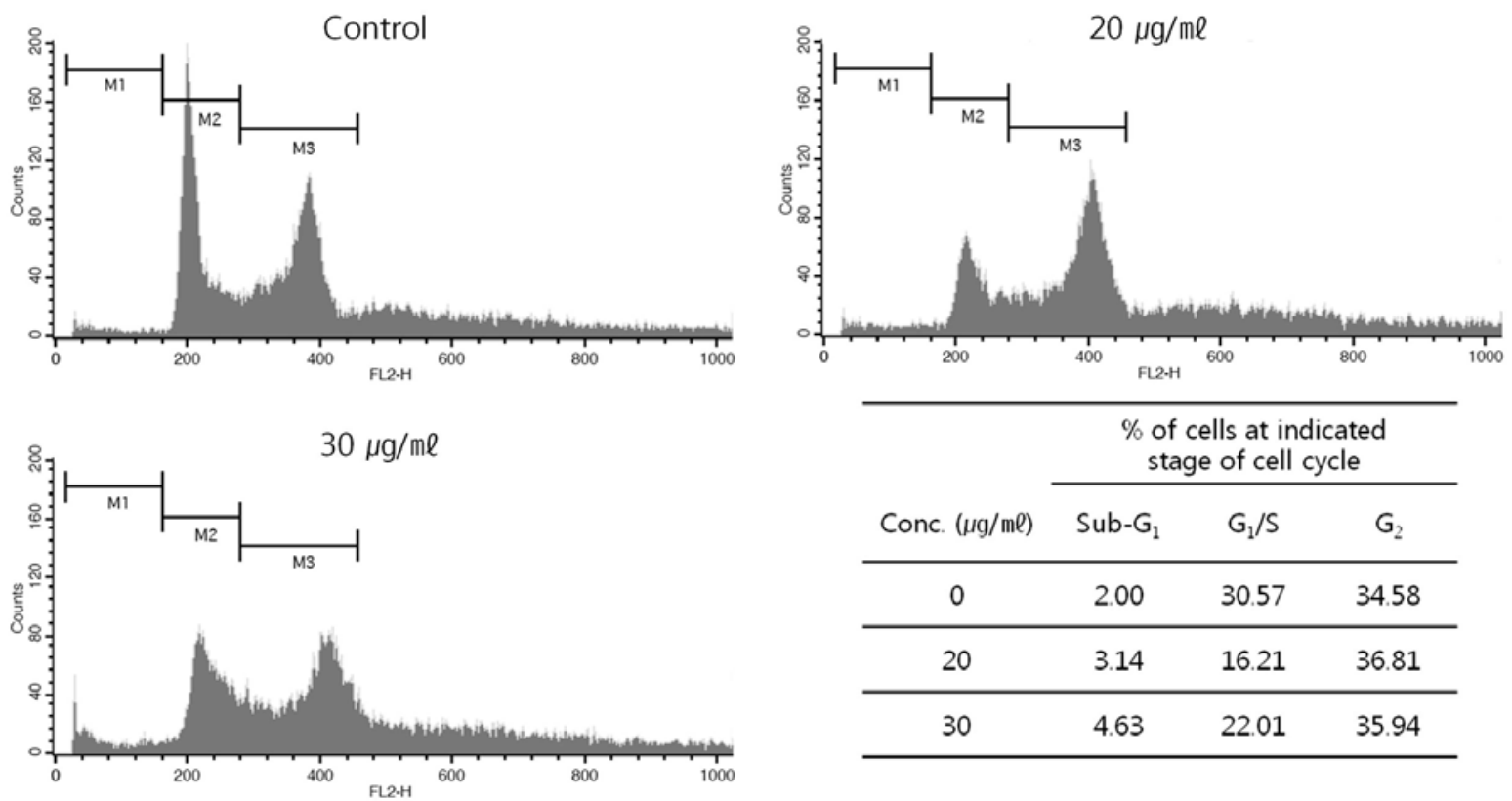

\begin{tabular}{cccc}
\hline & \multicolumn{3}{c}{$\begin{array}{c}\text { \% of cells at indicated } \\
\text { stage of cell cycle }\end{array}$} \\
\cline { 2 - 4 } Conc. $(\mu \mathrm{g} / \mathrm{m} \ell)$ & Sub-G & $\mathrm{G}_{1} / \mathrm{S}$ & $\mathrm{G}_{2}$ \\
\hline 0 & 2.00 & 30.57 & 34.58 \\
\hline 20 & 3.14 & 16.21 & 36.81 \\
\hline 30 & 4.63 & 22.01 & 35.94 \\
\hline
\end{tabular}

Figure 7. Cell cycle of the treated cells. Following the treatment with indicated concentrations of the extract for $24 \mathrm{~h}$, the ratio (\%) of cell distribution in the indicated stages was analyzed by FACS and summarized compared to non-treated control cells.

determine the pathways of the extract-induced apoptosis, the levels of FADD and phospho-FADD were examined using western blot analysis (Fig. 3C). The levels of FADD and phospho-FADD were increased after the treatment. These data suggest that the extract induced apoptosis following the death receptor mediated extrinsic pathway. Increased phosphoFADD stimulates binding of caspase- 8 to FADD, and this leads the activation of caspase- 8 , which can then cleave and activate downstream effector caspases such as caspase-3 or -7 leading the death of 267B1/K-ras cells (Fig. 3C) (24).

The mTOR pathway is a central regulator of cell growth that couples the control of protein synthesis to the availability of growth factors, nutrients, and energy. This is accomplished via the regulation of mTOR by multiple signals, including the PI3-kinase/Akt-FoxO pathway (25). Recently, the FoxO family of Forkhead transcription factors has been reported to regulate cell proliferation via the PI3K/Akt pathway (26). Therefore, to determine the status of PI3K/Akt-FoxO signaling pathway in $267 \mathrm{~B} 1 / \mathrm{K}$-ras cells, we treated 267B1/K-ras cells with the extract followed by analyzing the changes of phosphoryation of Akt and FoxO proteins using western blot analysis (Fig. 3D). Activated mTOR up-regulates Akt by its phosphorylation. However, exposure of the extract resulted in reduced phosphorylation of Akt and mTOR, but increased FoxO proteins, FoxO1, FoxO3a and FoxO4 in a dose-dependent manner. Decreased expression level of mTOR induces dephosphorylation of Akt which cannot repress the transcription factor, FoxO. Then expression level of FoxO is elevated (Fig. 3D). From these results, we suggest that PI3K/Akt-FoxO signaling pathway may be activated by the treatment of $S$. japonica extract in 267B1/K-ras cells.

Involvement of caspase-3 activation in apoptosis. The family of caspases can be divided into major subgroups based on substrate-specificity, sequence homology and biochemical function; in particular, caspase-3 plays a pivotal role in the terminal phase of apoptosis degrading several proteins. Before checking the expression levels of proteins affected by caspase-3, 267B1/K-ras cells were investigated for their caspase activity (Fig. 5A) to evaluate whether the extract affects caspases, the viability of cells were increased in case of treatment with zVADfmk, inhibitor of caspase. As shown in the results, more cells were alive when treated with both the extract and zVAD-fmk than treated with the extract alone (Fig. 5A). It suggested that the extract is able to affect the activity of caspases. The PARP protein is one of the cleavage targets of caspase- 3 and is also involved in DNA repair in response to environmental stress. Its molecular weight is changed from 116 to $86 \mathrm{kDa}$ by apoptosis. Another target protein of caspase-3 is DFF45 which functions in normal cells as chaperone for DFF40 during its synthesis. The association of DFF45 (or its isoform DFF35) with DFF40 inhibits the DNase activity of the latter (16). Caspase-3 cleaves DFF45, inactivates its inhibitory function on DFF40 and causes nuclear DNA degradation by DFF40, leading to cell death (Figs. 3C and 5B) (17). Caspase-3 also plays a role as a major protein to cleave lamins maintaining nuclear membrane structure. Lamins function in cell cycle control, DNA replication and chromatin organization, are are cleaved by caspase- 6 by activating caspase-3. During apoptosis, lamin is cleaved into a large (41-50 kDa) and small (28 $\mathrm{kDa}$ ) fragment, and the cleavage of lamins results in nuclear dysregulation and cell death (Fig. 3B) (27). Results indicate that the extract activates caspase- 3 and it cleaves specific target proteins leading to apoptosis (Fig. 3).

Immunofluorescence assay was also performed to prove the involvement of caspase-3 in the apoptosis event (Fig. 6). The cleaved caspase-3 was expressed in green fluorescent light as immunofluorescence makes use of fluorophores to visualize the location of the antibodies against cleaved caspase-3. In the cells treated with the extract, cleaved caspase-3 (green) exists around 
the cell with stronger fluorescence in comparison with untreated cells (control).

The extract induced cell cycle arrest at G2 phase. With the apoptosis induced by the extract, we also analyze distribution of cell cycle by FACS (Fig. 7). After the treatment, the cells were harvested and then distribution of cell cycle was analyzed. The harvested cells, which had fragmented DNA, were increased in G2 phase in DNA histogram from $34.58 \%$ at control (without the treatment) to 36.81 and $35.94 \%$ of the total population at 20 and $30 \mu \mathrm{g} / \mathrm{ml}$ of the extract, respectively. Western blot analysis was performed to determine whether cyclin-dependent kinase (Cdk) inhibitor $\mathrm{p} 21^{\text {waf1/cip1 }}$, phospho-Chk2, phospho-cdc2 and cdc25A are involved in the extract-mediated anti-proliferative effect on 267B1/K-ras cells (Fig. 3A). Increased expression level of phospho-Chk2 stimulates up-regulation of $\mathrm{p} 21^{\text {waf1/cipl }}$ proteins and down-regulation of phospho-cdc 2 and cdc $25 \mathrm{~A}$ in 267B1/K-ras cells treated with the extract in a concentrationdependent manner. Taken together, these results demonstrated that the cytotoxic effects observed in response to the extract are associated with the induction of apoptotic cell death.

Phosphorylation in Chk2, the checkpoint kinase, by DNA damage leads to phosphorylation of cdc25A. The cdc25 phosphatase may be responsible for activation of cdc 2 regulating the entry of eukaryotic cells into mitosis by phosphorylation (28). The tumor suppressor protein $\mathrm{p} 21^{\text {waf } 1 / \mathrm{cip} 1}$ acts as an inhibitor of cell cycle progression. Besides being an inhibitor of cell cycle progression, p21 acts as a mediator of the apoptotic pathway. Its enforced expression induces apoptosis or enhances the apoptotic response to chemotherapeutic agents (29).

The results shown in this study suggested that the extract (n-hexane sub-fraction) of S. japonica induced inhibition of cell growth resulted from multiple signaling pathways mediated by apoptosis and cell cycle arrest at G2 phase.

In conclusion, the anticancer effects of the $S$. japonica extract (n-hexane sub-fraction) on 267B1/K-ras human prostate cancer cells were assessed by detecting apoptosis and cycle arrest. The exposure of the cells to both 20 and $30 \mu \mathrm{g} / \mathrm{ml}$ of the extract for $24 \mathrm{~h}$ resulted in the inhibition of cell growth and morphology changes. The activation of caspases by calpain, FADD and FoxO makes the cells undergoing apoptosis. Elevated intracellular calcium concentration is assumed to activate calpain and to induce activation of other proteins involved in ER stress. FADD as intracellular domain of Fas, indicates that the extract has similar role to FasL. Thus, the extract can induce apoptosis by the activation of caspase- 8 and the caspase cascade. The cells can also undergo apoptosis when the FoxO transcription factor is inactivated. For the cell cycle arrest, the expression level of cell cycle controlling proteins such as phospho-Chk2, phospho-cdc2, p $21^{\text {waf1/cip1 }}$ and cdc $25 \mathrm{~A}$ were examined. The results suggested that the anticancer effects of the extract originated from a brown macro-alga, $S$. japonica act on apoptosis, cell cycle arrest and growth inhibition. The extract might be a useful candidate to develop compounds against human prostate cancer, and more studies will be required to find mitochondrial apoptosis and anti-metastasis effect using a further fractionized and selected single compound from this extract.

\section{Acknowledgements}

This study was financially supported by the Ministry for Food, Agriculture, Forestry and Fisheries, Republic of Korea.

\section{References}

1. Parda DS, Thraves PJ, Kuettel MR, et al: Neoplastic transformation of a human prostate epithelial cell line by the v-Ki-ras oncogene. Prostate 23: 91-98, 1993.

2. Wynder EL, Rose DP and Cohen LA: Nutrition and prostate cancer: a proposal for dietary intervention. Nutr Cancer 22: 1-10, 1994.

3. Giovannucci E: Epidemiologic characteristics of prostate cancer. Cancer 75: 1766-1777, 1995.

4. Stan SD, Kar S, Stoner GD and Singh SV: Bioactive food components and cancer risk reduction. J Cell Biochem 104: 339-356, 2008.

5. Booth E: Trace elements and seaweeds. In: Proceeding of the 4th International seaweed symposium. De Virville AD and Feldmann J (eds). MacMillan, London, pp385-393, 1964.

6. Yan X, Chuda Y, Suzuki M and Nagata T: Fucoxanthin as the major antioxidant in Hijikia fusiformis, a common edible seaweed. Biosci Biotechnol Biochem 63: 605-607, 1999.

7. Munro MHG, Blunt JW, Dumdei EJ, et al: The discovery and development of marine compounds with pharmaceutical potential. J Biotechnol 70: 15-25, 1999.

8. Rice-Evans C, Miller N and Paganga G: Antioxidant properties of phenolic compounds. Trends Plant Sci 2: 152-159, 1997.

9. Yuan YV and Walsh NA: Antioxidant and antiproliferative activities of extracts from a variety of edible seaweeds. Food Chem Toxicol 44: 1144-1150, 2006.

10. Lee NY, Ermakova SP, Zvyagintseva TN, Kang KW, Dong Z and Choi HS: Inhibitory effects of fucoidan on activation of epidermal growth factor receptor and cell transformation in JB6 C141 cells. Food Chem Toxicol 46: 1793-1800, 2008.

11. Lieberthal W, Koh JS and Levine JS: Necrosis and apoptosis in acute renal failure. Semin Nephrol 18: 505-518, 1998.

12. Zimmermann KC, Bonzon C and Green DR: The machinery of programmed cell death. Pharmacol Ther 92: 57-70, 2001.

13. Cryns VL, Bergeron L, Zhu H, Li H and Yuan J: Specific cleavage of $\alpha$-fodrin during Fas-and tumor necrosis factor-induced apoptosis is mediated by an interleukin- $1 \beta$-converting enzyme/Ced-3 protease distinct from the poly(ADP-ribose) polymerase protease. J Biol Chem 271: 31277-31282, 1996.

14. Kothakota S, Azuma T, Reinhard C, et al: Caspase-3-generated fragment of gelsolin: effector of morphological change in apoptosis. Science 278: 294-298, 1997.

15. Lazebnik Y, Kaufmann S, Desnoyers S, Poirier G and Earnshaw W: Cleavage of poly(ADP-ribose) polymerase by a proteinase with properties like ICE. Nature 371: 346-347, 1994.

16. Lazebnik YA, Takahashi A, Moir RD, et al: Studies of the lamin proteinase reveal multiple parallel biochemical pathways during apoptotic execution. Proc Natl Acad Sci USA 92: 90429046, 1995

17. Mashima T, Naito M, Fujita N, Noguchi $\mathrm{K}$ and Tsuruo T: Identification of actin as a substrate of ICE and an ICE-like protease and involvement of an ICE-like protease but not ICE in VP-16-induced U937 apoptosis. Biochem Biophys Res Commun 217: 1185-1192, 1995.

18. Sakahira H, Enari M and Nagata S: Cleavage of CAD inhibitor in CAD activation and DNA degradation during apoptosis. Nature 391: 96-99, 1998.

19. Sherr CJ: Gl phase progression: cycling on cue. Cell 79: 551-555, 1994.

20. Xiong Y, Hannon G, Zhang H, Casso D, Kobayashi R and Beach D: p21 is a universal inhibitor of cyclin kinases. Nature 366: 701-704, 1993.

21. Kwon O, Kim KA, Kim SO, et al: NF- $\kappa \mathrm{B}$ inhibition increases chemosensitivity to trichostatin A-induced cell death of Ki-Rastransformed human prostate epithelial cells. Carcinogenesis 27: 2258-2268, 2006.

22. Kuo PL, Hsu YL, Cho CY, Ng LT, Kuo YH and Lin CC: Apoptotic effects of Antrodia cinnamomeal fruiting bodies extract are mediated through calcium and calpain-dependent pathways in Hep 3B cells. Food Chem Toxicol 44: 1316-1326, 2006. 
23. Rasheva VI and Domingos PM: Cellular responses to endoplasmic reticulum stress and apoptosis. Apoptosis 14: 996-1007, 2009.

24. Muzio M, Chinnaiyan AM, Kischkel FC, et al: FLICE, a novel FADD-homologous ICE/CED-3-like protease, is recruited to the CD95 (Fas/APO-1) death-inducing signaling complex. Cell 85: 817-827, 1996.

25. Sabatini DM: mTOR and cancer: insights into a complex relationship. Nat Rev Cancer 6: 729-734, 2006.

26. Park SJ, Sohn HY, Yoon J and Park SI: Down-regulation of FoxO-dependent c-FLIP expression mediates TRAIL-induced apoptosis in activated hepatic stellate cells. Cell Signal 21: 1495-1503, 2009.
27. Oberhammer FA, Hochegger K, Fröschl G, Tiefenbacher R and Pavelka M: Chromatin condensation during apoptosis is accompanied by degradation of lamin $\mathrm{A}+\mathrm{B}$, without enhanced activation of cdc2 kinase. J Cell Biol 126: 827-837, 1994.

28. Sørensen CS, Syljuåsen RG, Falck J, et al: Chk1 regulates the $\mathrm{S}$ phase checkpoint by coupling the physiological turnover and ionizing radiation-induced accelerated proteolysis of Cdc $25 \mathrm{~A}$. Cancer Cell 3: 247-258, 2003

29. Gartel AL and Tyner AL: The role of the cyclin-dependent kinase inhibitor p21 in apoptosis 1 supported in part by NIH grant R01 DK56283 (to ALT) for the p21 research and Campus Research Board and Illinois Department of Public Health Penny Severns Breast and Cervical Cancer grants (to ALG). 1. Mol Cancer Ther 1: 639, 2002. 